\title{
SBPC（リラシリン）の組織移行
}

\author{
長崎三菱病院整形外科 \\ 茅 野丈二・瀬 良敬 祐 \\ 中 村 泰・高 橋 克 郎 \\ 西 野 美貴子
}

\section{Transfer of SBPC (Lilacillin) in Tissue}

by

\author{
J. Kayano, K. Sera Y. Nakamura \\ K. Takahashi and M. Nishino
}

Department of Orthopedic Surgery Nagasaki Mitsubishi Hospital

To determine the mode of transfer of antibiotics to focus, $2 \mathrm{~g}$ of sulbenicillin was intravenously injected into patients and changes in its concentration that took place during its transfer to tissues adjoining the lumbar spine were measured.

15 patients, aged from 19 to 59, suffering from the lumbarspine disorder were each given intravenous injection of $2 \mathrm{~g}$ of sulbeniciliin, and then spinous process laminae, ligament flavum, nucleus pulposus, and blood were sampled from each patient during surgery.

The tissue and blood samples thus collected were analyzed five times, with progressive delays of 15 minutes, 30 minutes, 60 minutes, 90 minutes, and 135 minutes, for comparative studies of sulbenicullin contents.

The maximum reading in ligament flavum was $9.1 \mu \mathrm{g} / \mathrm{g}$ given with the delay of 30 minutes, whereas it was $7.0 \mu \mathrm{g} / \mathrm{g}$ in spinous process laminae and $4.9 \mu \mathrm{g} / \mathrm{g}$ in nucleus pulposus measured with the delay of 60 minutes in either instance. Although the ratio of transfer was highest in ligament flavum, the tendency to remain in its tissue was not pronounced.

Low in concentration commonly in the three tissues of spinous process laminae, ligament flavum, and nucleus pulposus, sulbenicillin should be said almost ineffective against Gram-negative bacteria there. Also, it was found that sulbenicillin, though effective against Gram-positive bacteria, especially staphylococcus aureus, in ligament flavum and spinous process laminae, is less effective in nucleus pulposus.

\section{は じめに}

整形外科領域においては，抗生物質は多くの場合術 後感染予防に使用されている. そのため, ペニシリン 系, セファロスポリン系など広域スペクトルを持つ抗 生物質を使う機会が多い.しかし，新しい抗生物質の 開発にもかかわらず，骨䯣炎などはまだ完治の困難な 感染症として残っている.

一般に, 我々が抗生物質を使用する際には次のこと を考慮しなければならない。
1. 感染菌に対する抗生物質の最小阻止濃度.

2. 感染菌の抵抗性.

3. 抗生物質の病巣への移行性.

我々は今回第 3 の問題である病巣への抗性物質の移 行性を考える手がかりとして，スルベニシリンの腰椎 周辺組織への移行について調べた.

\section{I. 対象および方法}

対象は, 腰部椎間板ヘルニア，脊椎管狭窄症で手術 を受けた 19 才から 59 才までの 15 名の患者である 
表 1 症例々猃断名

\begin{tabular}{|c|c|c|c|c|}
\hline 症 & 例 & 年 & 性 & (体 $(\mathrm{kg})^{\text {重 }}$ \\
\hline $\begin{array}{c}1 . \\
2 . \\
3 . \\
4 . \\
5 . \\
6 . \\
7 . \\
8 . \\
9 . \\
10 . \\
11 . \\
13 . \\
14 . \\
15 .\end{array}$ & & $\begin{array}{l}25 \\
34 \\
46 \\
59 \\
28 \\
53 \\
19 \\
56 \\
37 \\
43 \\
56 \\
40 \\
41 \\
54 \\
33\end{array}$ & $\begin{array}{l}\text { 女 } \\
\text { 女 } \\
\text { 女 } \\
\text { 女 } \\
\text { 男 } \\
\text { 男 } \\
\text { 男 } \\
\text { 男 } \\
\text { 男 } \\
\text { 女 } \\
\text { 女魴 } \\
\text { 男 }\end{array}$ & $\begin{array}{l}52 \\
56 \\
59 \\
59 \\
68 \\
58 \\
54 \\
52 \\
78 \\
55 \\
43 \\
54 \\
53 \\
59 \\
71\end{array}$ \\
\hline
\end{tabular}

（表 1).

投与法は，手術開始直前あるいは直後にスルベニシ リン $2 \mathrm{~g}$ を one shot で静注し, 血液, 棘突起・椎 弓, 黄䩚帯, 髅核を適時採取した. 各検体を静注後 15 分, 30 分, 60 分, 90 分, 135 分の 5 回に大別し, 各 時間毎の濃度の平均值を出し比較検討した。

濃度測定は，武田薬品に 低頼し，Pseudomonas aeruginosa NCTC 10490 を用いたThin layar cupmethod で行なった.

\section{II. 結 果}

血液採取は 15 分から 135 分まで, のべ 30 例を行な った. ただし, 血中濃度の資料として, 他疾患で手術 を受けた患者 6 名分も加えた. 血中濃度は静注後直ち に上昇し, 15 分值の $123 \mu \mathrm{g} / \mathrm{ml}$ を最高に, 以後次第 に減少した.

黄䩲帯の採取は 15 分から 90 分まで，のべ 16 例を 行なった。濃度は 30 分值の $9.1 \mu \mathrm{g} / \mathrm{g}$ を最高に, 以後 減少した. 移行率は 60 分値の $17.5 \%$ まで上昇し, 以 後下降していった.

骨の採取は 15 分から 90 分まで, のべ 15 例を行な った. 濃度は 60 分值の $7.0 \mu \mathrm{g} / \mathrm{g}$ を最高に, 以後減 少した. 移行率は次第に増加し，90 分值の $16.9 \%$ が 最高であった.

䯣核の採取は 30 分から 135 分まで，のべ 10 例を行 なった. 濃度は 60 分值の $4.9 \mu \mathrm{g} / \mathrm{g}$ を最高に, 以後 減少した. 移行率は骨同様漸増し, 135 分値の $14.3 \%$ が最高であった（表 2).

\section{III. 考察}

今回採取した 3 組織のうち，黄靶帯，骨へは血管が 直接入り栄養しているのに対し, 髄核は正常椎間板で は線維軟骨輪の中にあり, 椎体加らの浸透液によって 栄養されている。皇故, ヘルニアを起てし，変性 し, 微小血管の進入があったとしても, 抗生物質の髄 核への移行は少ないものと予想していた．結果は，予 想通り, 最高值において黄䩲帯 $9.1 \mu \mathrm{g} / \mathrm{g}$, 骨 7.0 $\mu \mathrm{g} / \mathrm{g}$, 髄核 $4.9 \mu \mathrm{g} / \mathrm{g}$ と髅核への移行が最も思かった (表 2).乙れらの濃度変化をグラフにしてみると, 黄 勒帯は 30 分で, 骨, 䯣核は 60 分で最高値に達する が, 以後の減少の速度を見ると, 黄䩲帯が最むはや く, 骨, 髄核が同程度であった（図 1 ).

そこで, 各時間毎の血中から組織へのスルベニシリ ンの移行率を見てみると, 黄靶帯は 60 分で最高に達 し下降していくのに対し, 骨及び䯣核では時間の経過 とともに移行率が上昇し，骨では 90 分值の $16.9 \%$ が，䯣核では 135 分值の $14.3 \%$ が最高であった（図 2).

このことは, 黄勒帯では 60 分以後血中濃度の下 降 速度を上まわってスルペニシリンの排泄が急速に行な われていることを示す. これに対し, 骨, 䯣核では移 行速度は抒そく, 移行濃度も低いけれど屯, 一度吸収 されたスルペニシリンは長時間組織内に残存するとと がわかった。

次に, 血中濃度は高濃度に保たれながら, 黄靱帯, 骨, 䯣核は組織内濃度があまり上昇せず， 3 組織とも $10 \mu \mathrm{g} / \mathrm{g}$ 以下であり, 移行率も最高 10 数パーセント と低かった，そこで，乙のような濃度でどのような菌 
表 2 SBPC の組織への移行

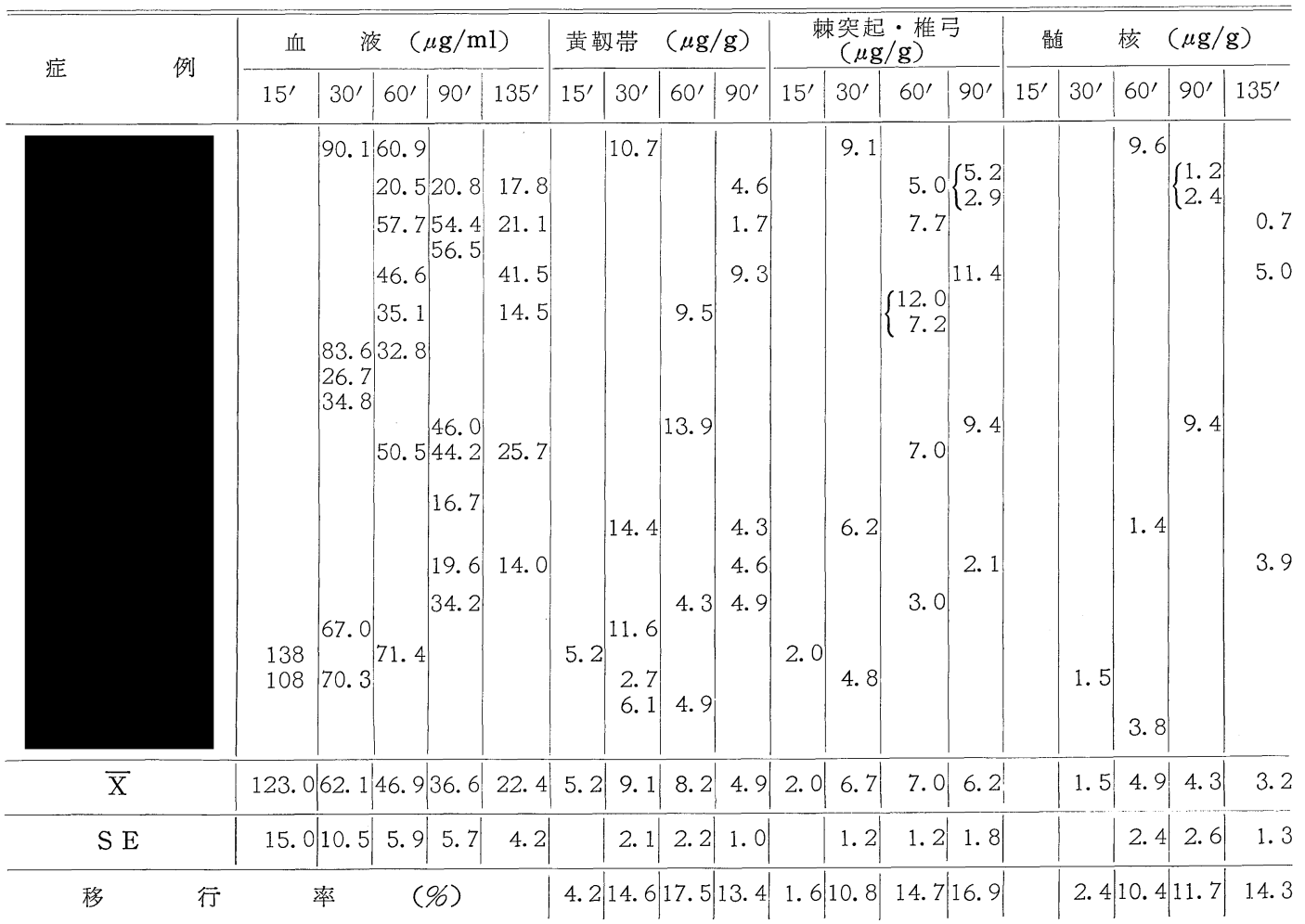

\section{SBPCの血液および組織への移行}

(SBPC 2.0g i.V.)
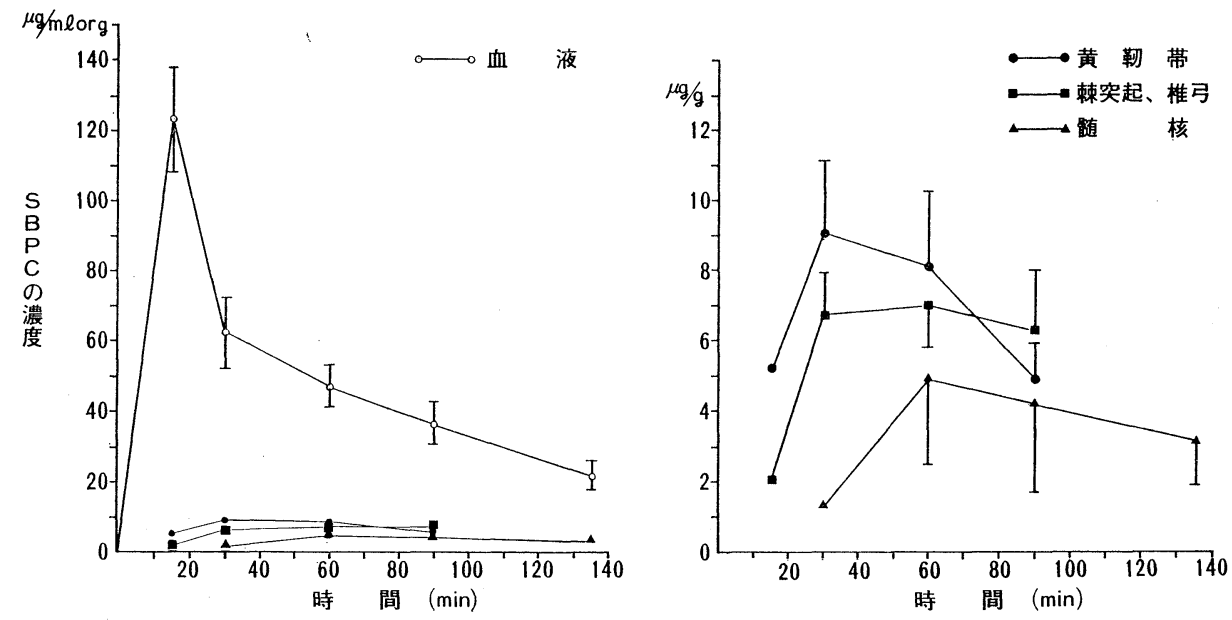

図 1 
移 行率 (組織濃度血液中濃度)

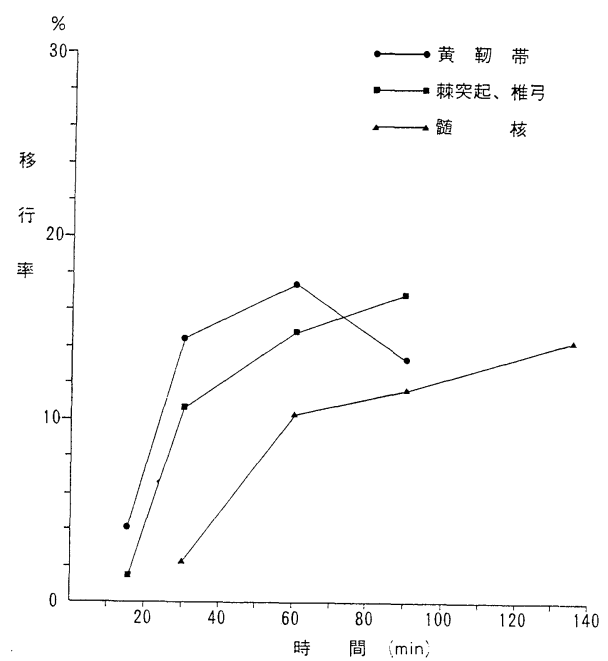

図 2

に対して有効性を持つのかを知るために，スルペニシ リンの MIC 分布と比較した（図 3 ).

血液では, 15 分值から 30 分值までで，大腸菌の 70 \%以上, 緑膿菌の $50 \%$ 以上に効果を示し, 比較的有 効である. 黄色ブドウ球菌, バクテロイデスに対して
は，135 分值であ $80 \%$ 以上を示し有効である.

黄靶帯, 骨, 䯣核では, 各最高值をとっても大腸 菌, 緑膿菌の $50 \%$ 以下で，有効性は期待できない. 黄色ブドウ球菌に対する有効性を見てみると, 黄靱带 では 30 分值から 60 分值まで $80 \%$ 以上を示し 有効で ある. 骨では 30 分值から 90 分值まで $80 \%$ 以上を示 し有効である. しかし, 䯣核では, 最高值の $4.9 \mu \mathrm{g} /$ $\mathrm{g}$ をとってみても $60 \%$ 前後で, 有効性はあまり期 待 できない，乙のことは，䯣核をそのまま椎間板におき かえることはできないが，黄靶帯，骨，䯣核の濃度か らみて, 椎間板炎や骨䯣炎などの感染症に対して, ス ルペニシリン $2 \mathrm{~g}$ 静注程度の量では 効果が 不十分で あることがわかった。

以上のように, スルペニシリンの腰椎周辺組織への 移行はあまりよくないてとがわかった。しいし，我々 は今回対象とした 15 名の患者に対し, 術後 5 日から 7 日間, 1 回 $2 \mathrm{~g}, 1$ 日 2 回のスルペニシリンの点滴 静注を行なったが，1例の術後感染むなかったととを あわせて報告する。

結語

スルペニシリン $2 \mathrm{~g}$ 静注により, 腰椎周辺組織への

\section{SBPCのMIC分布と組織への濃度移行}

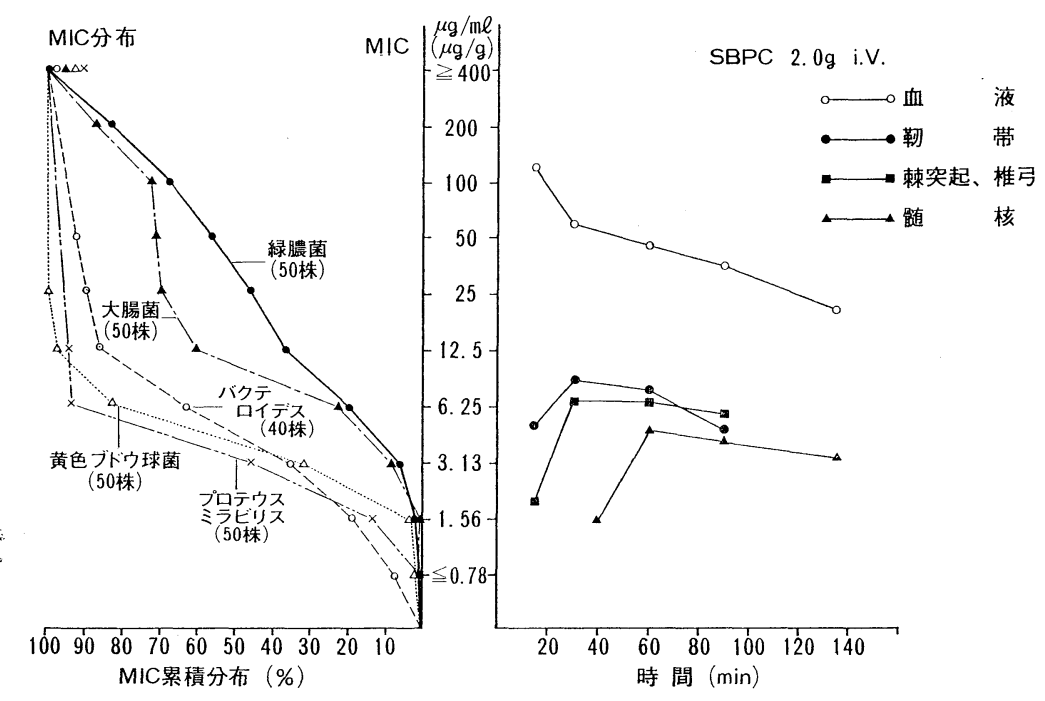

出口: Jap. J. Antibiotics, 34 1263, 1981 
移行を調べた.

1. 最高值は, 黄靶帯が 30 分值 $9.1 \mu \mathrm{g} / \mathrm{g}$, 棘突起 - 椎弓が 60 分值 $7.0 \mu \mathrm{g} / \mathrm{g}$, 䯣核が 60 分值 $4.9 \mu \mathrm{g} / \mathrm{g}$ であった。

2. 移行率は, 黄勒带, 棘突起・椎弓, 䯣核の順で あるが，黄靱帯は急速に上昇し，急速に下降するのに 対し, 棘突起・椎弓, 䯣核はスルペニシリンの残存傾 向が強いととがわかった.

3. スルペニシリン $2 \mathrm{~g}$ 静注では, 大腸菌, 緑膿菌 に対して 3 組織とも有効な濃度には達しない。しか し, 黄色ブドウ球菌に対しては黄勒帯, 欶突起・椎弓 において MIC 累積分布 80 \%以上に達するが，䯣核 では最高值でも $60 \%$ 前後までしか達しないてとがわ かった。

$$
\text { 文献 }
$$

1) 藤井千穂 - 他: Sulfobenzyl penicillin 投与 法に関する臨床的考察. 外科治療. $33: 207$, 1975.

2) 平井和樹 - 他: Piperacillin Sodium (PIPC) の骨髄内血液の移行濃度について, 診療々新薬. 13: 890, 1981.

3) 小出昭彦 - 他: SB-PC の臨床的研究一その腹 腔内投与について。新薬と臨床. 24: 1897, 1975.

4) 近藤 茂: 骨, 関節感染症, 特に開放損傷時に 扣ける化学療法について (第 1 報). 中部整災誌. 14: 424, 1971.

5) 近藤 茂: 骨関節感染症, 特飞開放損傷時に沶 ける化学療法について (第 2 報). 中部整災誌. 14: 434, 1971.

6)永山五哉：整形外科領域に招けるリラシリラシ リンの使用経験。新薬と臨床. 22. 1693. 1973.

7）桜井実・他：股関節手術に打ける骨䯣への Cephalothin の移行濃度. 整形外科. 29: 485, 1978.

8）桜井実・他：Cephalosporin 系抗生物質の 骨䯣内移行濃度について。臨整外。14：261，
1979.

9) 桜井 実: Cefotiam (SCE-963) の骨䯣血液 への移行について. CHEMOTHERAPY. 27: 138, 1979.

10）手束昭淿：抗生物質(セファゾリンナトリウム) の頸椎椎体周辺組織への移行. 臨整外. 12: 582, 1977.

\section{質 問 熊本大学整形外科 北川 敏夫}

棘突起などの移行の程度は他の Organ への移行に 比較したらどの位なのでしょうか.

解 答 長崎三菱病院整形外科 茅野 丈二 他組織，例えば，腹腔内臓器などに比し 移行は悪 W.

スルペニシリン $2 \mathrm{~g}$ は量的に少ない. セファロスポ リン系の方か文献的には移行がよい.

質問・追加九大整形外科 緒方 公介

(1)髄核は avascular tissue であるため，血中から の物質移動の経路に興味が持たれる.リラシリンはご のような経路を通って䯣核へ達すると考えておられる か? 即ち endplate route と annular route の どちらが重要でしょうか.

(2)椎間板ヘルニアの症例で髄核中の組織濃度を測定 しておられるが，ヘルニアにおちいった䯣核は，かな り viability あ落ちていると考えられる. 測定結果を ぞう意義づけられるか?

解 答 長崎三菱病院整形外科 茅野 丈二

1）正常椎間板では，抗生物質は椎体より線維軟骨 輪を通し浸透圧によって移行する.

2）ヘルニアを起とし変性した䯣核には毛細血管の 進入なども考えられ正常䯣核と全く同じレベルでは考 えられないが，移行濃度が低いことは疑いない。 